José Luis DA SILVA P.

Andrés Bello Catholic University

\title{
VENEZUELAN DEMOCRACY \\ IN THE 20TH CENTURY
}

\section{THE STRUGGLE BETWEEN THE MILITARY AND THE NON-MILITARY ${ }^{1}$}

ABSTRACT Twentieth-century Venezuela has characteristics that make it different in terms of the ways of conducting politics in the traditional way. Political parties of the twentieth century inaugurated a new political period. One reason for this may be found in the long dictatorship of General Gómez which lasted for more than three decades and which obliterated all vestiges of nineteenth century politics to the point that students will be called to establish innovative proposals. The mode of policy-making shows a difference in style between the military and non-military along with irreconcilable difference in the perception of democracy which they showed. One mentoring system will come increasingly into a conflict with another, in which there is an attempt to make the citizens bear republican responsibilities in order to feed a state that at times runs the risk of collapse due to the unmet requirements of the people, together with other requirements of the time.

KEY WORDS Democracy, dictatorship, civil, military, political parties.

The democratic life of Venezuela in the 20th century and the beginnings of the 21 st century pursued its legitimate ambition to attain democratic values which are shared, for the most part, by the countries of the world i.e. freedom of thought and opinion, political recognition, balance of the powers of the State, institutional

1 This article was submitted for publication before the death of Hugo Chávez. 
autonomy, equality before the law and social justice, health care and education which are appropriate for modern times, decent work conditions, political pluralism - all the elements necessary for the healthy development of individual and collective conditions of a society which unites traditional values with economic and technological progress.

The following text is a simplified political and historical essay whose aim is to present the most characteristic features of Venezuelan republican life in the 20th century through the concepts of dictatorship and democracy.

\section{FROM WARS TO DESIRED PEACE}

The 19th century ended with a revolution. In the May of 1899, a group of forty people under the command of Cipriano Castro began in Táchira the Revolución Liberal Restauradora. As they approached the capital, they gained the favour of the people and regional caudillos [leaders, warlords]. In October of the same year, Ignacio Andrade, President en funciones, seeing that he could not count neither on the support of important regional caudillos nor on the deputies of the National Congress, abandoned the country. Moreover, this event marked the end of the system introduced in 1870 by Antonio Guzmán Blanco and the Yellow Liberal Party of which he was the founder. The regime was organised around the figure of a political and military leader capable of forming regional alliances. Each region maintained its own army and economic autonomy under the authority of a military caudillo when the Republic rested upon the friendship, trust and loyalty of each caudillo to the main leader. Joaquín Crespo, President and caudillo of the Legalist Revolution, lost his life in 1898 when he was shot during a fight with the rebels. His physical death represented a crisis in the hierarchy and a challenge to select the true successor to the Presidency of the Republic.

Until 1899, the political arrangement created by Antonio Guzmán Blanco was experiencing its terminal crisis. It was a system based on an alliance of the principal regional caudillos in the country to whom the main caudillo, who served as a common point of reference, in exchange for loyalty to this network, granted considerable autonomy and the management of affairs related to their respective regions, including their revenue and the ability to maintain state armies. ${ }^{2}$

Continuous dissent regarding political decisions resulted in the deterioration of social and economic conditions of the population who lived in prolonged unrest. The political parties broke into temporary factions which struggled with each other to maintain their particularistic interests to the detriment of the interest of the republic.

Violence ravaged the country throughout the 19th century, frequently in the form of a civil war. Under the pretext of a "Revolution" robberies and lootings were perpe-

2 D. Bautista Urbaneja, La politica venezolana desde 1899 hasta 1958, Caracas 2007, p. 7. 
trated and lives were destroyed amid persistent international protests. In reality, the Country was not able to guarantee peace and fulfil its external obligations. ${ }^{3}$

Under these circumstances, the accession of Cipriano Castro to the position of supreme chief of the Republic brought hope to the people. Being free from political pressure, he allowed the exiles to return and embraced a policy of restoration of the country; the motto which symbolised his political agenda - "new people, new ideals, new procedures" - seemed to be in keeping with the tone of the new century. Political adherence quickly followed. The youth turned out to play a significant role in an attempt to approach the leader with a request to be brave to implement the laws that were necessary for the country.

There are young professionals, academics, most famous writers and poets, lawyers and engineers who represent the best there is in Venezuelan culture and who signed a petition in which they hope that the Law "will not shatter in the clutches of violence (...) We live as a nomadic tribe in pursuit of ideals which have become reality in more fortunate countries. The frightened voice of the official who denies all the obligations to the citizen still resounds and the wind still sweeps away the shreds of law across the plains and mountains."

Unfortunately, the highly rhetorical speech of the government was not trustworthy - the promises were profanated time and again by the caudillos. Rebellions and uprisings began to fill the pages of republican history. Nevertheless, we are going to see a change in the way of managing the government that differed greatly in the 19th century as opposed to the 21 st century. Little by little, Cipriano Castro began to give up some of his power to regional governments, mainly the ability to maintain resources necessary for the management of armies. Since 1904, the possibility of providing resources and weapons to the Presidents of the regions was eliminated by constitutional reform. The task of forming a national and professional army rested with the Central Authority. In 1903 the creation of a Military Academy was decreed. ${ }^{5}$ The old caudillos began to disappear one by one at the hands of Vicepresident Juan Vicente Gómez who was about to bring the army under his control, and as we will later see, the whole Country. This situation brought about the elimination of political parties as well as their 19th-century politics. This scenario was to give way to the longest period of dictatorship in the Venezuelan republic. The political parties of the 19th century disappeared, leaving room for new actors, ideologies and procedures characteristic of modern political parties that will emerge during the course of the 20th century. ${ }^{6}$

As the central government fostered military discipline, the social and economic conditions became precarious to the point that the means to pay off the external debt were lost. Tensions began to mount to such an extent that European governments, with Germany and England at the head, began to raise a blockade of Venezuelan ports, de-

J.C. Rey, El sistema de partidos venezolano, 1830-1999, Caracas 2009, p. 45.

R.J. Velásquez, 'Cipriano Castro' in De la revolución restauradora a la revolución bolivariana. La historia, los ejes dominantes, los personajes, Caracas 2009, p. 479.

5 D. Bautista Urbaneja, La politica venezolana desde 1899 hasta 1958, pp. 10-11.

6 We recommend work: J.C. Rey, El sistema... 
manding that the debt be paid. When the dispute reached its highest point, the government of the United States of North America intervened as a mediator, under the pretext of the Monroe Doctrine. President Theodore Roosevelt managed to avoid external occupation and to reach a consensus between the parties involved.?

The nationalist position of Cipriano Castro's government is striking in this event. Having no audacity to face the European powers, he resorted to influence public opinion through a highly rhetorical speech in which he intended to win the support of the people. This way he avoided being perceived as the one responsible for the blockade.

(...) For Castro, the blockade was an occasion to deliver a fervent nationalistic speech. He coined (...) a phrase which entered the Venezuelan nationalistic discourse and which constitutes one of the most durable and common phrases: "an insolent plant from abroad has infested the sacred soil of the mother country" $(. . .)^{8}$

Nationalistic discourse was present in Venezuela of the 20th century. It was used by both dictatorships and democracies when opportunity arose because it was a means of gaining favour for the government. In the face of great economic difficulties in a country already ravaged by uprisings and the fighting between the factions of the caudillos, it was not surprising that the people desired peace at all levels of national life.

This peace would be offered by Juan Vicente Gómez - at the cost of eradicating all political discourse which was contrary to his simple vision of the world. The Republic required not only property but also labour and hard-working, tacit people, and, to say the least, peace that would endure for more than his 27 years of duty. It must be pointed out that peaceful succession in the government should respect the electoral procedures authorised by the Constitution, with the exception of Isaías Medina Angarita, a military overthrown in 1945; Rómulo Gallego, a non-military overthrown in 1948; Marcos Pérez Jiménez, a military overthrown in 1958 and the controversial case of Hugo Chávez Frías on the 11 th of April 2003. ${ }^{9}$

It is a fact that in the Venezuelan imagination there exists a peculiar combination of a military government and the maintenance of peace in the society at the cost of having to give up political liberties, and, in some cases, the freedom of thought and opinion. It is this militarism which tended to be confused with dictatorship as the maintenance of peace tended to be confused with peace itself. For some reason, at the beginning of a change, societies tend to perceive an order-bringing value in dictatorial regimes. It is only during their course does it turn out that other values such as freedom and respect for other people become more important.

As it is, dictatorship always tends to proceed along this course: by some, sometimes by the majority, it is received with praise, and accepted by the rest... Because of the savage and vengeful character of initial dictatorship of any kind, the society interprets it solely as this: peace. And in order to preserve it, the whole world is inclined to endure not only

D.A. Rangel, Gómez el amo del poder, Caracas1975, pp. 112-119.

8 D. Bautista Urbaneja, La politica venezolana desde 1899 hasta 1958, p. 10.

9 Please see the work: S. La Fuente, A. Meza, El acertijo de abril. Relato periodístico de la breve caída de Hugo Chávez, Caracas 2004. 
the worst calamities but also to find a justification and rationalisation for the actions of the government and general favour. ${ }^{10}$

\section{DICTATORSHIP}

Let us begin with a basic definition. Dictatorship means: the suppression of law with the aim of assuming power in a violent or non-violent way to correct mistakes and restore the true order of a State $;{ }^{11}$ with a special feature that the new power tends to unite the executive, legislative and judicial functions of the State in one person. ${ }^{12}$

The governments of Cipriano Castro, Juan Vicente Gómez, Carlos Delgado Chalbaud and Marcos Pérez Jiménez come under this definition. All four were military people. The first two received their military distinctions in wars, the last two by receiving a degree in the Military Academy.

Cipriano Castro rose to power at the head of the Revolución Restauradora. His mission was to bring restoration and order. To achieve these goals he did not proclaim a free government but a government formed by new people with a more open mentality. This intention turned out to be rejected by his own actions because he kept all power in his own hands. In 1908, Cipriano Castro fell ill and had to travel to Europe. His position was taken by his trusted man, General Juan Vicente Gómez, Vicepresident of the Republic. He took advantage of his absence to assume power without shedding a drop of blood. Indeed, this transmission of power is not seen as a revolution but as an evolution. It is not a revolution nor a change, not even a rehabilitation (...). ${ }^{13}$

Promises are made about civil rights, freedom of opinion and the freedom of the press. The emergence of the review Alborada and the journal El Universal in 1909 serve as good examples of a Country which desires to enter the 20th century. However, with the course of time, reality becomes different. Since 1913, concentration of power and eradication of all discourse contrary to the dictate of the caudillo is apparent. The peace that we mentioned in the first passage is possible under the iron order of Castro - there is no room for politics.

Peace attained through the use of arms is guaranteed in such a way, in spite of a different discourse, only through the institutionalisation of force. From the point when - by Gómez's decision - there is a breakdown and personal gain monopolises it (....). ${ }^{14}$

This situation prevailed until his death on December 17, 1935. From this time, the formation of a professional and unified army falls under the command of the President.

10 M. Caballero, Gómez, el tirano liberal, Caracas 1995, p. 350.

11 C. Schmitt, La dictadura. Desde los comienzos del pensamiento moderno de la soberania hasta la lucha de clases proletarias, Madrid 2007, p. 26.

12 N. Bobbio, Estado, gobierno y sociedad. Por una teoría general de la política, México 1999, p. 229.

13 M. Caballero, Gómez..., p. 113.

14 A. Aguiar, 'Nacimiento y afirmación de la República militar. La fragua de Venezuela como Estado Nación' in De la revolución restauradora a la revolución bolivariana. La historia, los ejes dominantes, los personajes, Caracas 2009, p. 36. 
For a period of 27 years, Venezuela would live under the boot of Gómez, a situation which had to do with the Armed Forces, the multinational corporations, an efficient network of governmental information and the intellectuals - the latter were influenced by Positivist thinking and justified the existence of a Gendarme Necesario. The formula for the progress of the society was based on the combination of the people and the government. The latter had an idiosyncratic nature, the paternal and firm hand - it was a caudillo who knew how to run the country and who was at the same time a teacher of the people, instructing them not to cheat in political matters - a synonym of division, faction, war and death.

Peace was possible in a dictatorship. Given the social, ethnic and geographic characteristics of the population, the people were not able to establish a democracy - for this, the future citizen must have been created, as well as infrastructure, means of terrestrial communication, agricultural and petroleum economy, stable and respectable international connections - all this was hindered by the onslaught of prison terror and repression of political ideas.

As this process was developing, the country would seek more and more advanced forms of government until it reached such republican and democratic forms to which it prematurely aspired in the 19th century (...). In this sense, the dictatorship of Gómez is a necessary stage of our social evolution, probably a long period, but a transitory one as any other stage. ${ }^{15}$

This period of transition did not seem sufficient to create a citizen capable to experience democracy. For this reason, in the 50 s, we will see a new period marked by dictatorship. The overthrow of Rómulo Gallegos on 24 November 1948 gave way to ten years of military government that can be divided into three phases.

These ten years are associated with the name of Marcos Pérez Jiménez and his dictatorship. However, if we want to keep to the facts more carefully, this decade has to be divided into three parts. The first part extends from 24th of November 1948 to the 13th of November 1950. During these two years, the head of the government is Carlos Delgado Chalbaud as President of the Junta Militar de Gobierno which followed Gallegos. This Junta was also composed of Marcos Pérez Jiménez and Luis Felipe Llovera Páez (...). Delgado was assassinated on the 13th of November. Thus a period which would last until the appearance of abogado Germán Suarez Flammerich, as in this case Pérez Jiménez is already the strong man of the government. The culmination of these years are the elections of 30th November 1952 and a lack of recognition of the results of the elections by the officials of the Armed Forces. This led to a coup d'etat of the 2 nd of December and the dictatorship of Pérez Jiménez proper which lasted five years and two months. ${ }^{16}$

The dictatorship of Pérez Jiménez represents a period of political repression and management at the discretion of the institutions of the State. As in the case of Gómez, a part of the population saw order, progress and peace. Moreover, we see the introduction of monumental projects as the Ciudad Universitaria in Caracas, las Torres del

\footnotetext{
15 D. Bautista Urbaneja, La politica venezolana desde 1899 hasta 1958, p. 29.

16

Ibid., p. 91.
} 
Silencio, motorways, etc. However, there were two very symbolic moments which cannot be passed over because they show the autocratic and egoistic style of this government - firstly, the elections to the Constitutional Assembly in 1952 and secondly, the plebiscite of 1957.

The elections of 1952 were promised by the Junta de Gobierno which overthrew Gallegos in November 1948, however, because Chalbaud was assassinated, the project to restore the path to democracy was put aside. The elections were a farce. The government-favoured candidate, Marcos Pérez Jiménez, asked the authorities of the National Electoral Council to modify the results, to sideline the democratic candidate and winner of the elections, as well as his accompanying members who would form the majority in the Assembly - a fact which clearly manifests a coup d'état disregardful of the rules of the game. As the results were manipulated, the self-proclaimed President was free to choose the members of the assembly. They ordered the making of a new Constitution in 1953, made according to the desires of the dictator. With this, a period of six years set on, after which new elections were held. The Communist Party of Venezuela and the Democratic Action (AD) of social democratic roots were proscribed, then followed the Democratic Republican Union (URD), many of its leaders were expelled and Copei, with a Christian social spirit, managed very cautiously to maintain a minimum of activities.

Prisons began to fill with political prisoners and dissenters. National Security was the police branch of the Government. This body possessed considerable means to spy on, incarcerate all who came under suspicion of conspiracy. The list of disappearing people worried the people. The politics of fear together with the idea of the Armed Forces tightly allied with the President gave the impression of indestructibility of the regime.

\section{TRANSITIOON. BETWEEN DICTATORSHIP AND THE DEMOCRACY}

With the death of Gómez, it seemed that the transition has reached its end. It was time to choose a successor to the liberal tyrant. The conditions of the country were not the same as in 1908, in 1936 there was a need to organise better structures, aware of the need of changes necessary for the State and the society to embrace the era of progress and modernity proper to the 20th century. Once more, a trusted man, Eleazar López Contreras, a military man by education, as opposed to Castro and Gómez who were military people through the power they held, entered the scene. López Contreras was the product of the institutionalisation of education in the military forces.

Having gained their experience during the revolution, Gómez's men won their ranks on the field of battle, but with little strain: many "generals" have reached this rank by their own designation. But since 1903 things began to change, and since 1910 it was understood that in order to reach the top of the hierarchy, one had to finish a military school. ${ }^{17}$

17 M. Caballero, Gómez..., p. 204. 
It is a fact that despite the long period of dictatorship peace was achieved and it prevails to this day not without difficulty in recent years, with a delay of more than 15 years into the 20th century.

The new government established new rules of the game: a reduction of the presidential mandate, legalisation of political parties, although censorship of the press was still maintained. Everything seemed to indicate that the transition would be a democratic one. Even though the demands were great, the events of February 1936, the demands of the students and the unions obliged the government to change its plans. As a response, he asks the people to be "calm and prudent".

From the beginning, López Contreras took a course different from that of his predecessor. He gave up the most easy way to leave things as they were, to continue the ways of Gómez and his acolytes and to maintain existing structures, he decided to muster up his courage and to pursue the way of democracy and liberty with determination. And this he did in the most appropriate way in order to safeguard against any possible return to dictatorship and that the transition would preserve the peace which cost so much to achieve. ${ }^{18}$

History was on its way, the Grand Elector chose under pressure rather than by conviction a young successor who just left the military academy - Isaías Medina Angarita - who would assume the position of President from 1941 to 1945. Social exigencies required changes that would bring about the recognition of political, social rights and the rights of freedom of opinion and information. Even though Medina maintained a form of continuity in his management of the State, in fact he introduced legislative reforms indicative of an introduction of democratic channels that were visible in the number of legalised political parties.

Medina Angarita in his first messages proclaimed continuity, but when we look at it, he did so in a subtle way and when we read between the lines, he actually denied continuity when he proclaimed that different administrations that follow each other should leave a homogeneous state of affairs for the posterity. And when he affirmed that if one realises clearly that the Government is an abstract entity and that it does not have a personal name, one reaches an inevitable conclusion that by avoiding personal vanities it has to maintain a sense of continuity between various administrations who understand not only the necessities of the present moment but also have plans for the future (...). ${ }^{19}$

It is a question of a slow and gradual process whose aim is to make the people understand that they are going to live in times of democracy. In this point, we will see that visions which focus around a common objective, nevertheless manifest disparities with the course of time. In the eyes of the government, the people were not in the condition to directly choose their administrators - the voice of the Grand Elector and the confirmation of the National Congress were still necessary - whereas the political parties, especially the Democratic Action thought that the people were in the condition to assume sovereignty and express their will about the course which the State should take.

\footnotetext{
18 R. Moleiro, De la dictadura a la democracia. Lindero y puente entre dos épocas, Caracas 1992, p. 47.

19 R.J. Velásquez, 'Aspectos de la evolución política de Venezuela en el último medio siglo' in R.J. Velásquez et al., Venezuela Moderna. Medio siglo de historia 1926-1976, Caracas 1979, p. 75.
} 
Moreover, the differences between the management of Lopez and Medina created a controversy in the military that intensified on 18 October 1945. The monolithic unity of the army which was the driving force of State politics since the beginnings of the century, reached its end. The government of Medina Angarita was overthrown. There is no historical consensus about this fact. Some consider it a coup d'état, other call it an October revolution. It is certain that the government tried to delay reforms permitting general and secret ballot of all Venezuelans until 1951. The opponents of the government thought that the time for reform has come and that it was a necessary decision that could not be postponed any more. It will be seen how the reformist ideas confronted revolutionary ideas and that the latter emerged victorious. The people in the year 1945 were mature enough to set up democracy and even approve a civil government. The revolution of October 1945, the new constitution of 1947 which established the secret and general ballot as the right of all Venezuelans over the age of 18 regardless of sex was, among other things, crucial to make the Venezuelans realise the benefits of the system of liberties and respect before the law. It was this constitution that allowed to preserve for a few months the democratic government of Rómulo Gallegos which was chosen in the elections.

Nevertheless, we must say to be true to the facts that the experience of Eleazar López Contreras and Medina Angarita also allowed a gradual opening toward peace and democracy. The short spell of Rómulo Gallegos that lasted some months showed the exercise of democracy to the people. The indelible mark left by the dictatorship of both Gómez and Pérez Jiménez deterred any ideas of going back to the dark times of fear and terror of autocracy. The will of the people should repose in transparent order, in which motivation would be expressed by the majority, not by a clique. New times require a definition of politics which would facilitate the establishment of alliances and friendship based on the struggle for liberty, the right of the citizen and the will expressed through suffrage both within the country as well as abroad. Power should repose in institutions, in collegial bodies, made duly legitimate by democratic and liberal structures, marking off any movement toward egoism, toward a man with an iron hand who administers the material and human resources of the Nation according to his whims as pernicious. Times change and Venezuela did not want to remain in the past having made the decisive step toward Democracy.

\section{OF JANUARY 1958 AND THE CIVIC TURN}

In 1956, especially toward the end of that year we begin to see clandestine movements encouraged by the political parties. There were some groups and their outstanding leaders, many of whom belonged to the generation of the year ' $28^{20}$ and were exiled.

20 We are referring to the generation of young university people who protested against the repressive politics of Juan Vicente Gómez's government. Many of these young people will become great actors of the political scene in the history of modern Venezuela. 
In 1957, things began to be complicated for the government. More and more sectors began to separate themselves from the government. In the Church, The Archbishop of Caracas, Monseñor Rafael Arias Blanco, denounced the violence of the government. The subject of the elections was discussed within the government, according to what was established in the text of the Constitution approved in 1953. The decision that was taken demonstrated authoritarian inclinations of the dictator and his desire to remain in power. Instead of calling elections and allowing political parties to participate in the competition, the government put forward and approved the organisation of a plebiscite - a situation that was not stipulated by the Constitution. The question directed to the elector was to know whether he desired that Marcos Pérez Jiménez should remain in the Presidency for more five years. Because of the policy of terror and the lack of minimal guarantees for the electorate, the government achieved an overwhelming victory. Pérez Jiménez won by an overwhelming majority of votes: 2374790 votes against $384182 .^{21}$

In his commemorative discourse held on 23 January 1958, the orator Miguel Otero Silva applied himself to the task of recalling the last days of December 1957 until the day when the dictator was overthrown. We will include extracts in our present essay in order to demonstrate the value of the aforementioned date for Venezuelan democracy.

In December 1957, the people were overwhelmed by great difficulties and by the disgust caused by the plebiscite, a manipulation of the government to remain in power. The people were aware of the extensive character of the struggle, there were no ways to receive any help and the time was wrong to falter in their intentions. Nevertheless, and without anybody expecting it (...) a breath of rejuvenating and invigorating hope inspired the birth of this new year and their Armed Forces. ${ }^{22}$ This desire to overthrow the government demonstrates a rift between the government and the Institution of Castro. Even though the "the clarion call began with the rotors and engines of airplanes", actions against the government extended also from other sections of the Armed Forces. Little by little, it became manifest how one of the most important Institutions of the country made efforts to support the unflinching will of the people to restore freedom. And not only did they manage to support the people in the time prior to the events of $23 \mathrm{rd}$ of January, but also, as the dictatorship was overthrown, demonstrated complete support of constitutional norms as well as an extraordinary conformity with democratic ideals - an act which brings praise to the Institution of Castro, when it used arms for the exclusive defence of justice and liberty. It was the knowledge of the inestimable value that respect for judicial and constitutional order has for the Nation, values that they knew how to maintain. Moreover, under the authority of the provisional government remained one of the figures (...) of most delicate social sensibility and unflinching will to support our democratic life permanently (...). ${ }^{23}$ Having made these remarks, our orator expresses praise for

21 D. Bautista Urbaneja, La politica venezolana desde 1899 hasta 1958, p. 103.

22 M. Otero Silva, 'Tres discursos' in compilación del Concejo Municipal del Distrito Federal, Caracas 1964, p. 7.

23 Ibid., p. 8. 
the Armed Forces of Venezuela - an act of gratitude in recognition of their great efforts and front-line participation in the celebrations on the 23 of January.

It is time to review the most important actor, the people. The one who adhered at 5 and 6 as to drink, as pointed out by Miguel Otero Silva in his discourse of January 1959 , never doubted the value of their life, when there was the question of fighting for the liberty of the Republic. For doctor De Sola the people did the right thing when they involved themselves body and soul to the advancement of the inestimable values of democracy. They fought with the only weapons they had in their hands: stones, sticks and bravery that never faltered within their bare chests.

Finally, the main protagonist of the movement took the stage. The humble people, brave and generous, confronted with their honest hearts the gunshots of the scoundrels and humidified with their blood the seeds of triumph. It was a collective effort of those who instead of enshrining their own names opened the pages of our history for La Charneca and Quebrada Caraballo, El Mamón, and El Manguito, Lomas de Urdaneta, La Ceiba, El Guarataro, El Polvorín and the group who through valiant fighting and heroic resistance won the right to exchange their primitive denomination for the one of " 23 of January". It was a brave act of those who raised stones and sticks against guns and bombs.... ${ }^{24}$

They were conscient people who vigorously entered the pages of history by making themselves visible on the street, standing face to face with the rigours of dictatorship, people who were not afraid about their lives because their hopes were set on higher ideals. Life without freedom, life in which there is no respect for dignity, is not worth living. For this reason, bravery as a human virtue makes its appearance. Our orator mentions the most humble districts of the capital city. By mentioning them, he makes public recognition of the nobility of the inhabitant of Caracas of humble condition, the one who had only "sticks and stones" to confront the dictatorship. Great was the torpidity of the government against which the people decided to take to the streets and express with their cries, "Down with the chains!"; with their bodies made weary by such great fear, raising cries to restore liberty and respect for the human condition. No doubt, we are in one those special moments of National History when the people decide to break away from the atavisms and break forward to the centre of events, without fear, without complexes, but clear in their intentions. We see a group of men, women and young people who do not take their fleeting lives into account when it comes to the preservation of the highest values of the Fatherland. Such a demonstration of patriotic values is seldom found in the history of peoples. The will of the people expressed itself clearly and categorically. The repudiation of the regime made one see that the desires of the population went in the opposite direction to any possible incursion of particularistic groups who intend to assume power with weapons. One needs courage to confront the guns of the regime with a bare chest. Can such firm action be overpraised, action of the people with a vocation for duty who understood that the only way out from the social convulsions was the adoption of the high values of liberty and justice embraced within the mark of

24 Ibid., pp. 8-9. 
democracy? The object of the struggle was to make democracy cease to be a simple object of adoration and make it a part of living experience - a heroic act which served to make public the beginning of a new social contract. The need to embrace democracy was indicative of a desire to break from the cycle of contemporary history. This was the form of government for the rest of the 20th century and the beginning of the next one.

So great were the hopes put in democracy that maybe, in a straightforward manner, it was thought that with its help the problems of the Republic would be eradicated. Nevertheless, in its time it served as a stimulus to make a decisive step toward the construction of a new country full of hope and positive energy. Everyone shared the same will, everyone acted in solidarity and thus established the foundations of a new future. The overthrow of the regime was seen as a legitimate act that gives rise to politics agreed upon by the majority. The general strike on 22 January was a prefiguration of the events on the morning of 23 January. This was a display of one of the most important features of democracy - social solidarity.

A people who make themselves visible through such daring deeds must be taken into account by the actors of the political scene of the Nation as well as the ruling class. Our orator calls to the members of the Council, and through them, to the government, that they should consider the requirements of the people who did so much for the cause of democracy. The labours of the government should be directed toward the attainment of better conditions of life. Those in power should listen to the needs of the people who want jobs, higher education and social peace.

(...) in compensation of so much young blood that was spilled, of such heroic struggle, basic well-being (...): a roof to shelter oneself from bad weather, a table which would not fail to supply three daily rations and a school where the children would learn about a new fatherland which would distribute its goods among everyone and where everyone would enjoy liberty, justice and culture! (... $)^{25}$

Special attention of the ruling class is required to fulfil the terms of the compromise between the government and the governed. There is a need of a strategy of work, planning of work, a project for the present, with social well-being in mind. Democracy must materialise in facts. Just like a conveyor belt, it must run all of its wheels so that it works for the benefit of the majority. The desired politics must rejoice in the satisfaction of the basic needs of the governed, as well as the preservation of dignity of the people and their rights. The time has come to test the spirit of the politicians with whom rests the trust of the majority. The ruling politicians must respect this compromise. The people are in front of them and are ready to enforce their requirements. To fulfil his obligations, the ruling politician who wants to manage the government must make a virtue out of respect for the will of the people.

Such was the way of thinking of the people who assumed power without any other credentials than an unflinching will to set the foundations for a consolidation of a democratic State of law and a system of justice and social security for everyone... ${ }^{26}$

\footnotetext{
25 Ibid., p. 9.

26 Ibid.
} 
Despite the fact that many of them did not have much experience in the management of government, (...) they were aware of the general desire to convert into reality the unwritten postulates which served as firewood for the movement. ${ }^{27}$ What is certain, the orator points out, is that they cannot make a step back and that they must stand on top of things, the more so because the beginning corresponds with one the most significant dates in National History. The solidification of results already achieved will strengthen the ties between the government and the governed. The events of 23 January 1958 were still fresh in memory because they served as common reference point and a compromise on the part of all the sectors in pursuit of ideals that would bring liberty and justice to the fatherland.

We must not forget the events of 23 January which meant the exchange of authoritarian vices for public virtues. The world of light which illumines civil rights against the excesses of a disgraceful period in history, a great change in the vision of things. This date should serve as a stimulus for unflinching effort to see the fulfilment of hope in the social, economic and cultural processes of the country. The sacrifices should be compensated by governmental strategies that bring about an increased hope in the future of the Nation. ${ }^{28}$

This movement should not be seen as a revolutionary event but as the end of a disastrous period in the history of the Republic and the birth of a new dawn, shining with hundreds of rays of democracy. The dark clouds of dictatorship, which granted peace to the citizens only at the price of submission to the armed hand of terror and death, should stay behind. We do not see in the events of 23 January a typical ideological revolution, but a necessity to establish the rule of justice and liberty. Let us repeat that we are not talking about liberty and justice in a narrow, not to say exclusive sense but we are talking about Justice and Liberty in capital letters.

We are invited to recognise a more modest destiny, as any revolution may suggest that we are facing nebulous or unattainable ideals. The objective of this is based on the trust in the institutions, and for this reason its respective officials must set a good example of decency and support judicial norms. The governed, on their part, must set a good example of civic virtue that manifests itself in the unflinching effort to defend the laws of the Republic. The official and the governed must be respectful to democratic values. As opposed to the speakers of previous years, our orator tends to dislike the term Revolution because he consideres it to have an affinity with tropical revolutions, (...) Without reaching to the tropical hyperbole by calling it a revolution (...). ${ }^{29}$ Because this term may assume different connotations in the speech of national leaders: firstly, a pronounced glibness being far from imparting a progressivistic feel, leaves a subtle trace of romantic nostalgia for paradise lost; secondly, an illegitimate analogy with external processes where the causes are brought forward to conclude upon the necessity of a rev-

Ibid., p. 10.

28 J.L. Da Silva, 'Partidos y pueblo en la naciente democracia venezolana de 1959, a través de la experiencia político-periodística de Miguel Otero Silva', Cuadernos UCAB, № 9, Caracas 2011.

29 M. Otero Silva, 'Tres discursos', p. 9. 
olution differ in form and in content when we consider the clumsiness of comparing historical processes which seem to be similar.

To consider the events of 23 January as a living sign of a revolution would be to impart an ideological tint which, according to our orator, the said date does not possess. There are other considerations that should be taken into account when we examine the events which took place at that time. We should avoid the pitfalls of a political vision which tries by its argumentation to identify that which happened on native soil with other events which happened in different historical and geographical conditions. Moreover, these attempts at a political exegesis should be aimed at the improvement of government action. The initiatives should have a clear pragmatic outlook to improve the living conditions of the people. The question is not to change the institutions but to recover the sense of civic society which operates within the conditions of liberty and justice. From this perspective, it is advisable that political leadership should design a strategy or workplan which could successfully solve the problems faced by the collectivity.

The question is not to consider historical events as processes of a revolution but as means to provide solutions to the most everyday of problems which are ultimately the same problems which the dictatorship could not solve. For this reason, the strategies which originate in the spheres of power must be aimed at the stimulation of national production as well the sustainable increase of places of employment; at the creation of a system of social security which guarantees health care as well as make the greatest possible effort to improve education and propagation of culture; finally it must not neglect the guarantees necessary for the faithful execution of laws whose spirit should be manifested in the defence of civil rights. Our orator does not want to make use of subtle ideological techniques to pave the way of good versus evil, but invites us to make a plain and open reflection upon the real importance of political action, which consists in the provision of benefits to the greatest number of people who inhabit a given country, striving to make the most needy of the inhabitants count within the political, social and economic structures and give them an opportunity to improve their living conditions. This is a vision of a clear utilitarian turn, but it intends to replace the political diatribes whose sole purpose is to emphasise differences and the possible moral values in which a theory may surpass other theories with a vision which asks politics directly to get to grips with reality in order to find ways which could improve the citizens' quality of life. Fortunately, continues our orator, such was the vision of the people with a vocation for duty who took charge of the nascent democratic era beginning with 23 January 1958.

Such was the way of thinking of the people who assumed power without any other credentials than an unflinching will to set the foundations for a consolidation of a democratic State of law and a system of justice and social security for everyone. There was no one from the sectors of political parties and no one had any experience in the exercise of power. But everyone felt the imperative to convert unwritten slogans into reality which served to stimulate the recently formed movement. ${ }^{30}$

30 Ibid., pp. 9-10. 
Strict adherence to the concept of democracy served as the foundation for the formation of a free Republic, capable of breaking away from links with autocratic forms of power. It was a source of opinions through which all the different areas of political, social and economic life shared a common view that existence should agree with not only national reality but continental reality and the reality of the world as well. Only in this way the political debate could anchor its ideological tenets within democracy and at the same time political factors would feel obliged to materialise their wishes, many of which were already lying at the heart of the Venezuelan people. The change of the democratic course was the central concept of the new order of events, indicating the birth of the proper republican life, aware of the needs of the Venezuelan people, and which could prevent possible external interference or possible persuasion, some of them showing external influence, an manifested themselves as divorced from national sense. The continuously cherished hope was about to be fulfilled: to invest the power and the legitimacy of the mandate in the will of the people to pursue the road of peace and well-being.

\section{DEMOCRACY}

Democracy can be defined through its three constitutive elements. They appear in multiple combinations: The rights of the citizen, the balance of interests of the citizens through jurisprudence and the political rights of the citizen.

Every democracy involves three principal institutional mechanisms. The first one combines the reference to fundamental rights with the definition of citizenship. This is the basis of constitutional instruments of democracy. The second one combines respect for fundamental rights with the representation of interests which is the principal object of judicial codices. The third one combines representation and citizenship which is the principal function of free parliamentary elections. Consequently, we may refer to a democratic system whose constitutional, legal and parliamentary elements put into action three principles: limitation of the State with regard to fundamental rights. social representability of political actors and citizenship. ${ }^{31}$

The governments of Rómulo Gallegos, Rómulo Betancourt, Raúl Leoni, Rafael Caldera, Carlos Andrés Pérez, Luis Herrera Campins, Jaime Lusinchi and Hugo Chávez Frías come under this definition. Only Caldera and Pérez were re-elected for a second time and not immediately; whereas Chávez was re-elected for three consecutive times and recently aspires to be re-elected for the fourth time. All except the last one are non-military people.

It will be the task of democratic governments to activate resources which will stimulate development in the fields of society, education, social security, culture and politics as well as a just distribution of the riches generated through labour not only in its productive aspect but also and especially in the formative aspect of bringing

31 A. Touraine, ¿Qué es la democracia?, Buenos Aires 1998, p. 110. 
more and better citizens. Thus, it is not enough to praise the longevity of the constitutional text in comparison with other texts within the republican life of the country. The priority is to inscribe into the law a programmatic sense. The constitution of 1961 which emerged in the spirit of unity which surged on the 23rd January 1958, proceeded to avoid the hindrance of social mobility and the vital development of all Venezuelans.

The journey undertaken in 1958 was not easy. Social, economic, educational and social security indices were not satisfactory. On the one hand, the government of Rómulo Betancourt had to confront military uprisings both from the right and left sides and the danger of upheaval. On the other hand, the primary task was to promote government action regarding the provision of minimal services to the people and to transmit the Presidency of the Republic by democratic means to a successor chosen by popular will. $^{32}$

As far as Raúl Leoni, whose term ended in 1969, is concerned, his government established the foundations for peace in the country. Moreover, he permitted the legalisation of all political parties: He talked all the time about leading a government with a broad outlook and national sense (...). ${ }^{33}$ As far as the economy is concerned, the policy of limiting concessions to multinational petroleum corporations (initiated by Betancourt) stands out.

The next government was that of Rafael Caldera. He won the elections as the first candidate of the opposition. The democratic system, which recently passed its tenth year of existence since 1958, faced its first institutional trial. The operating government did not influence the will of the people according to its whims but respected it. It should be noted that Rómulo Betancourt claimed that Venezuelan democracy may consolidate itself when it will successfully pass the trial of three successive elections. Moreover, the elections of 1968 were the third ones and to give more weight to Betancourt' statement, the opposition triumphed in Betancourt in those elections. It was crucial that the transmission of power should occur without any problems. ${ }^{34}$

The government of Caldera sought inspiration in social cristianismo and was a founder of the Copei party as opposed to previous governments, whose ideology was based on social democracy and whose party held the name Acción Democrática (Democratic Action). Efforts to maintain political peace are continued together with a greater control over natural resources, especially petroleum. The political society was faced with a trial that it could not pass between 1945 and 1948, given the early stages of entry into democracy. This was an important contribution of the government which terminated its activity in 1974.

The next government belonged to the ranks of the Acción Democrática subsequently referred to as $\mathrm{AD}$. Carlos Andrés Pérez gave a new stimulus to the economy,

32 L. Silva Luongo, De Cipriano Castro a Carlos Andrés Pérez (1988-1979). Hechos, vivencias y apreciaciones, Caracas 2000, pp. 440-449.

33 Ibid., p. 527.

34 D. Bautista Urbaneja, La politica venezolana desde 1858 hasta nuestros dias, Caracas 2009, p. 47. 
the State grew to a disturbing size and faced the danger of corruption. The petroleum and metallurgic industries were nationalised. "Get to work", repeats continuously Carlos Andrés Pérez, urging the Venezuelans to work (....). ${ }^{35}$ It was a very dynamic and responsible government in all spheres of national life. Democracy consolidated itself and the risks of a military uprising were reduced.We could say that thanks to impressive petroleum revenue Venezuelan democracy enjoys a healthy existence. Unfortunately, it still did not care about public and private education capable of bringing an understanding of the importance of decent conduct and not embezzling the money of the Republic for one's own use.

The next government was that Luis Herrera Campíns, made from the ranks of the Copei. Herrera was aware that Venezuelan society must grow democratically, improve its educational policy and develop its road infrastructure in all directions.

The idea of participative democracy does not only served to define its relations regarding the sector of the capital; it rather encouraged political leaders to cope with the dangers which the country will face as it enters the 21 st century. ${ }^{36}$

The next government was that of Jaime Lusinchi, elected with a majority, lead a government based on his AD party. He had to take into account the important majority of the representatives of his party to the National Congress. Social tranquility was at its highest level, to the point that Lusinchi was the President who finished his term with the highest popularity rating. Perhaps in order to improve the capacity of institutional channels for the flow of democracy in the Country, the Copre was created in $1984 .{ }^{37}$ After twenty years of democracy everything indicated that the time has come to initiate a process of improvement in order to prevent the weakness of the system.

The last ten years (1989-1999) were a difficult trial for Venezuelan democracy, and it is the only historical period that requires separate study. Presidency would be assumed by two ex-presidents Carlos Andrés Pérez (who did not finish his term) and Rafael Caldera. With the latter occurred a break from the two-party system that dominated the political scene since 1974. It must be mentioned that Caldera broke from his Copei party and established an alliance within an egoistic party. We may say that the model in which political parties were the main elements of democracy with political parties as the main elements reached its end.

Hugo Chávez assumed Presidency in 1999. He promised and fulfilled his promise of establishing a new Carta Magna (1999). He speaks about a political move-

\footnotetext{
A. Aguiar, 'Nacimiento y afirmación..., p. 208.

6 Ibid., s. 220.

37 “(...) the Comisión Presidencial para la Reforma del Estado (Copre) [the Presidencial Commission for the Reform of the State] was established by a decree issued on 17 December 1984, under the consideration that Venezuelan society required the adoption of measures which would ensure the establishment of a modern State, in essence democratic and efficient, in which the participation of citizens could be a viable element in the process of taking decisions by political powers"; C. Banko, 'De la descentralización a la nueva geometría del poder', Revista Venezolana de Economía y Ciencias Sociales, 2008, Vol. 14, No 2 (may.-ago.), p. 169.
} 
ment and not about a political party, a movement which lasted (with some changes) until $2012,,^{38}$ on the eve of presidential elections, upon the winning of which Chávez would have his third consecutive, uninterrupted presidential mandate. This was a government with a socialist ideology, unfortunately marred by corruption and disorganisation in governmental politics, despite resources coming from petroleum revenue never before seen in republican history of the country were strikingly weak. Nevertheless, as we owe an answer to the question asked by the reader of these words, why did Chávez maintain power, we say that he did so owing to his strong personality, his charisma, his abilities of a prudent politician who knew how to influence the people. He had the exceptional ability to communicate his ideas. In his case, we are talking about a democracy with a strong egoistic accent which endures among servile powers with little autonomy and individual opinion. We hope that this period will not be a transition toward a non-democratic model. One more aspect that makes this military government different from democratic civil governments is that it tries to organise the people around the leader and treats the opposition as enemies that must be vanquished. Since 1958, the conciliatory pacts between the political parties made it clear that there was only one society and that political preferences should not be a cause of exclusion, the concept that the people were not hostages of one group. Everyone was a part of one nation. Nowadays things have changed. In an act of commemoration of the Battle of de Carabobo, President Hugo Chávez said that whoever is not a "chavista" [supporter of Chávez], he is not a Venezuelan. ${ }^{39}$ We may return to this phrase time and again, because it makes the sense of exclusion clear, a characteristic feature of egoistic governments with power above all other powers of the State.

\section{CONCLUDING REMARKS}

The road traversed by the people to see their democratic wishes materialised was not simple and much less quicker. Even today, there are reasons to continue the struggle for a better and more effective democracy with transparent institutions and noble governments. In the 112 years including the 12 years which correspond to the new century, we have a certain whole which demonstrates certain details which cannot pass unnoticed: first, the desire to live in peace; secondly, 49 of dictatorship as opposed 67 years of de-

38 In a public act of January 2005, Chávez announced that in the future the revolutionary project will become the socialism of the 21 st century. He admitted himself that this was a decision taken unexpectedly without a public discussion and was preceded by a discussion within the party, who nevertheless manifested in many ways their consent, however in an a posteriori manner. The same situation occurred with the decision to substitute the MVR with a new party (Partido Socialista Unido) [United Socialist Party], whose presidency was accepted by acclamation, without the necessity of a formal vote, with vicepresidents appointed freely likewise by a directive whose prior selection and final designation was his own work; J.C. Rey, El sistema..., p. 250.

39 A fragment of a speech presented by the President before the members of the Venezuelan army on 24 June 2012 . 
mocracy, with a distinguishing element that of the total, 65 years fall to the totality of military governments and 47 fall to non-military governments; thirdly, the emergence in the 30's, of political parties which are still active today, but not as dynamic as previously; fourthly, the egoistic turn in the execution of political power and the State; sixthly, the significance of the people and the society according to the persons in power; and finally, in the 201 years of republican life (1811-2012) we register 26 Texts of the Constitution ${ }^{40}$, of which, 15 belong to the 20th century, 3 of which were written in the civil spirit.

\section{REFERENCES}

Aguiar A., 'Nacimiento y afirmación de la República militar. La fragua de Venezuela como Estado Nación' in De la revolución restauradora a la revolución bolivariana. La bistoria, los ejes dominantes, los personajes, Caracas 2009.

Banko C., 'De la descentralización a la nueva geometría del poder', Revista Venezolana de Economia y Ciencias Sociales, 2008, Vol. 14, № 2 (may.-ago.).

Bautista Urbaneja D., La politica venezolana desde 1899 hasta 1958, Caracas 2007.

Bautista Urbaneja D., La política venezolana desde 1858 hasta nuestros días, Caracas 2009.

Bobbio N., Estado, gobierno y sociedad. Por una teoría general de la politica, México 1999.

Caballero M., Gómez, el tirano liberal, Caracas 1995.

Da Silva J.L., 'Partidos y pueblo en la naciente democracia venezolana de 1959, a través de la experiencia político-periodística de Miguel Otero Silva', Cuadernos UCAB, № 9, Caracas 2011.

La Fuente S., A. Meza, El acertijo de abril. Relato periodístico de la breve caida de Hugo Chávez, Caracas 2004.

Moleiro R., De la dictadura a la democracia. Lindero y puente entre dos épocas, Caracas 1992.

Otero Silva M., 'Tres discursos' in Concejo Municipal del Distrito Federal, Caracas 1964.

Planchart Manrique G., 'Constituciones de Venezuela' in Diccionario de Historia de Venezuela, Vol. A-D, Caracas 1988.

Rangel D.A., Gómez el amo del poder, Caracas 1975.

Rey J.C., El sistema de partidos venezolano, 1830-1999, Caracas 2009.

Schmitt C., La dictadura. Desde los comienzos del pensamiento moderno de la soberania hasta la lucha de clases proletarias, Madrid 2007.

Silva Luongo L., De Cipriano Castro a Carlos Andrés Pérez (1988-1979). Hechos, vivencias y apreciaciones, Caracas 2000.

Touraine A., ¿Quées la democracia?, Buenos Aires 1998.

Velásquez R.J., 'Aspectos de la evolución política de Venezuela en el último medio siglo' in R.J. Velásquez et al., Venezuela Moderna. Medio siglo de historia 1926-1976, Caracas 1979.

40 G. Planchart Manrique, 'Constituciones de Venezuela' in Diccionario de Historia de Venezuela, Vol. 'A-D, Caracas 1988, pp. 843-864. 
Velásquez R.J., 'Cipriano Castro' in De la revolución restauradora a la revolución bolivariana. La historia, los ejes dominantes, los personajes, Caracas 2009.

Vallenilla Lanz L., Cesarismo democrático. Estudios sobre las bases sociológicas de la constitución efectiva de Venezuela, Caracas 2000.

José Luis DA SILVA P., Profesor Titular. Doctor of History in 2005. MA in Philosophy in 1992. Director of Center of Research and Humanistic Education. Director of post-graduate studies in the area of the humanities and education. Professor of pre-graduate and post-graduate studies in the Schools of Philosophy and Social Communication of the UCAB. Author of more than 30 articles published in national and international reviews. A researcher of Pei classification B. 